\title{
Seasonal Variation of Physico-Chemical Parameters and Their Influence on Phytoplankton Community of Muthupet Estuary, Southeast Coast, Tamil Nadu, India
}

\author{
Suganthi $A^{1}$, Venkatraman $C^{1}$, Bharath $B^{2}$, Perinbam $K^{2, *}$ \\ ${ }^{1}$ Marine Biology Regional Centre, Zoological Survey of India, India \\ ${ }^{2}$ PG and Research Department of Botany, Government Arts College for Men (Autonomous), Affiliated to University of Madras, India
}

Received January 24, 2020; Revised March 2, 2020; Accepted March 12, 2020

Copyright $₫ 2020$ by authors, all rights reserved. Authors agree that this article remains permanently open access under the terms of the Creative Commons Attribution License 4.0 International License

\begin{abstract}
Physico-chemical parameters of freshwater are most important factor for diversity and density of phytoplankton community. Hence, the present study was intended to evaluate the seasonal variation on physico-chemical parameters such as rainfall, temperature, $\mathrm{pH}$, salinity, dissolved oxygen and their relationship with phytoplankton community of Muthupet estuary. The seasonal variation of nutrients like nitrate, phosphate and silicate was recorded to determine the utilization of nutrients by phytoplanktons in aquatic environment. The results exposed that physico-chemical parameters showed significant difference among the seasons. The nutrient dynamic of Muthupet estuary exhibits considerable seasonal variation due to the rainfall and nutrient utilization of autotrophs. There are totally 14 species of phytoplankton under three different groups namely Bacillariophyceae, Dinophyceae and Cyanophyceae was recorded. The highest phytoplankton density was recorded during summer season $\left(18541.67 \mathrm{~b} \pm 3934.52 / \mathrm{m}^{3}\right)$, while lower in monsoon seasons. The statistical analysis of physico-chemical parameters showed significant variation among seasons and the diversity indices of phytoplankton were high during post monsoon for both Simpson and Shannon indices and also on Evenness. The correlation analysis exposed that physico-chemical parameters and nutrients are effective dynamics to control the seasonal variations on phytoplankton diversity. Therefore, the present study reveals that Muthupet estuary has rich in phytoplankton community due to presence of high nutrient content and consisting of appropriate environmental factors.
\end{abstract}

Keywords Muthupet Estuary, Physico-Chemical, Nutrients, Phytoplankton, Diversity Indices

\section{Introduction}

Wetlands are major ecosystem on earth; especially coastal wetlands play a significant role as a transition of water body between the land and the sea. The wetlands are distinctive due to hydrology and ecotones between terrestrial and aquatic ecosystems [1, 2]. The wetland contains divergent hydrology escort by flood pulse encourage changes in biodiversity, especially plankton communities, nutrients are diluted in high water and concentrated in low water [3]. In flooding period, the water level was increased and reduces the environmental heterogeneity through submerging of aquatic habitats and connectivity was maximized [4]. After draw away of flood, various water bodies gradually improve their characteristic properties, increasing uniqueness, habitat and biotic communities [5]. India contains longer coastal line of 8,129 $\mathrm{km}$, among this $6,000 \mathrm{~km}$ are rich in estuaries, brackish water, creeks, lakes and lagoons [6]. In particular, southeast coast of India has broader coastline known as Bay of Bengal, connecting with various major rivers and richer in marine fauna and flora [7].

Muthupet estuary is a marine-coastal wetland with a wide diversity of habitats and ecological features, including intertidal salt marshes, forested wetlands, mangroves and brackish to saline lagoons. The soil types commonly found in this area are alluvial, red ferruginous or lateritic, irugur or black, arenaceous and kallar. Muthupet has been declared as a Ramsar site and is now among globally important wetlands of the world. A large number of water birds visit the wetland every year from October to January from different parts of the world.

Phytoplankton's are major component in marine ecosystem, which releases oxygen in the time of photosynthesis and serves an energy exchange process. In food chain, phytoplankton is primary source and donates 
the major fishery resource all over the world. Moreover, they adjust the food web and too dependable for formulation of biological community $[8,9,10]$. The dynamics and structure of phytoplankton in aquatic ecosystem was influenced mainly by physico-chemical parameters [11]. In the ecosystem physicochemical parameters changes encompass significant impact on species to facilitate and live within them. Physiochemical parameter such as temperature, salinity, $\mathrm{pH}$, total organic carbon, nutrients and dissolved oxygen were varied in different seasons, which could play vital role in periodicity, population distribution, qualitative and quantitative composition of ecosystem and ecology [12].

Many studies have been carried out so for on physicochemical parameters of various estuaries of India [13, 14]. Marine phytoplankton reliant on nutrients and physical parameters present in a sea. Phytoplankton abundance, growth and metabolism regulations are based on the availability of nutrient [10]. Therefore, the present study is necessary to provide information on seasonal fluctuations of physico-chemical parameters and distribution of phytoplankton's community in Muthupet estuary during the year 2015.

\section{Materials and Methods}

\subsection{Sampling}

Water samples, primary production experiments, phytoplankton collections were made fortnightly preferably on every full moon and new moon days at Muthupet estuarine for the period of January 2015 to December 2015 (Figure 1). The data obtained for seasonal variations in distribution and abundance of phytoplankton diversity in relation to environmental parameters.

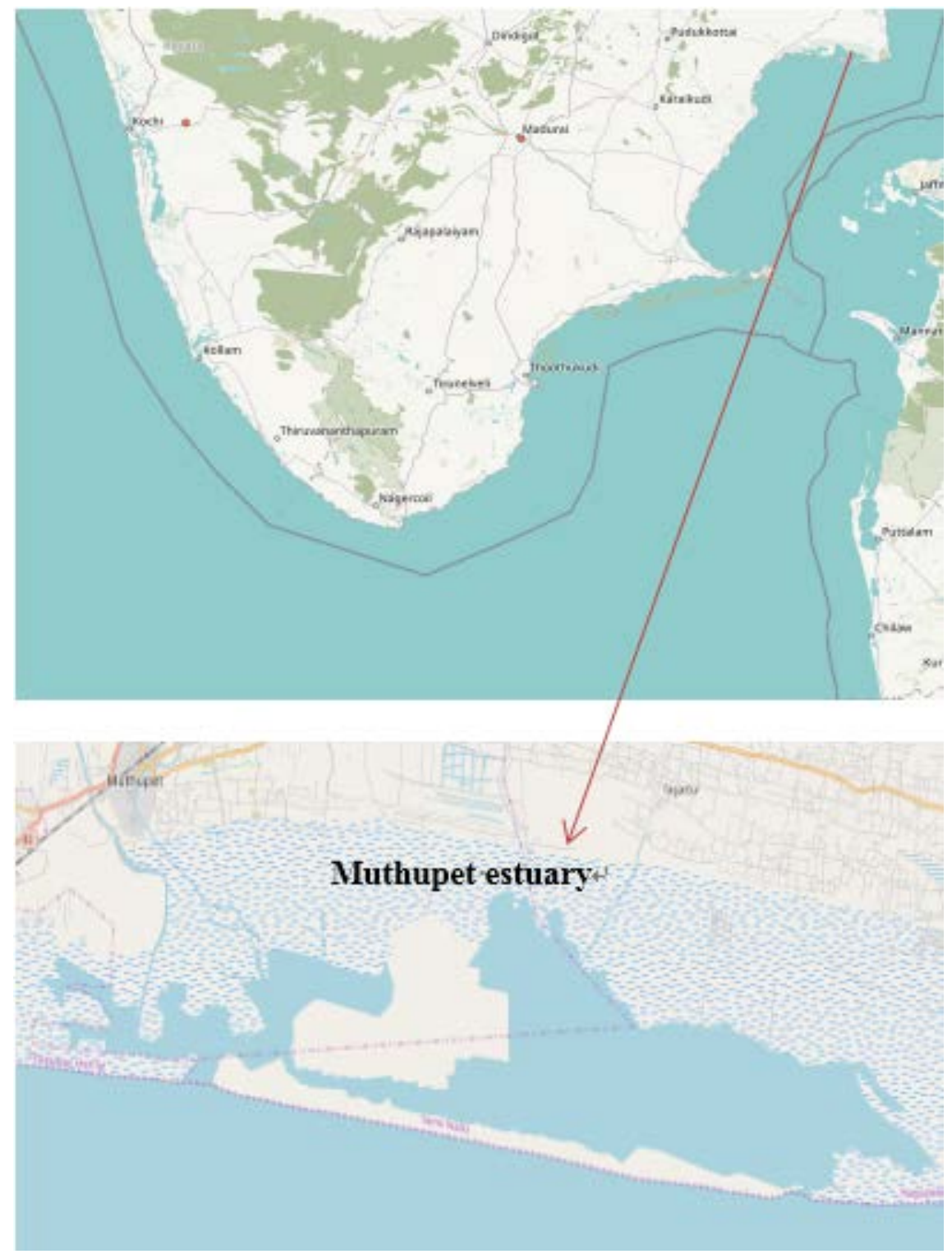

Figure 1. Location map of study area Muthupet Estuary 


\subsection{Physico-Chemical Parameters}

The rainfall data was obtained from Government Regional Meteorological Department, Chennai. Atmospheric and water temperatures were measured using standard mercury filled centigrade thermometer of $0^{\circ} \mathrm{C}$ to $110^{\circ} \mathrm{C}$. Temperature measurement was made by immersing the thermometer into the water surface for a sufficient period (till the reading stabilizes) and the reading was taken, expressed as ${ }^{\circ} \mathrm{C}$. The $\mathrm{pH}$ of water was determined by using $\mathrm{pH}$ meter. The salinity content of water samples was measured by method of Altaff [15]. Dissolved oxygen content was evaluated according to the method of Jayaraman [16]. The nutrient content of water samples was analyzed by adopting the standard methods such as Silicate [17], Phosphate [18] and Nitrate [19].

\subsection{Primary and Net Productivity}

Primary productivity was estimated based on changes in dissolved oxygen using light and dark bottle method as described by Strickland and Parsons [20].

\subsection{Phytoplankton}

Samples were collected from surface water by horizontal towing a conical net $(0.35 \mathrm{~m}$ mouth diameter), made up of blotting silk (cloth No. 30 mesh size 48 um) for thirty minutes and were preserved in 5\% neutralized formalin. Phytoplankton were identified the standard works of Desikachary [21] and Santhanam et al. [22].

\subsection{Statistical Analysis}

One-way ANOVA was performed using Duncan Multiple Range Test (DMRT) to observe the seasonal variation in nutrients and phytoplankton community. Statistical analysis or diversity index is the mathematical measure of species diversity in a given community. Based on the species richness (the number of species present) and species abundance (the number of individuals per species), are two types of indices, namely Shannon Index $\left(\mathrm{H}^{`}\right)$ and Simpson Index (D). The distribution of individuals over species is called evenness. It makes sense to consider species richness and species evenness as two independent characteristics of biological communities that together constitute its diversity. Correlation data analysis among all the parameters was performed to find out any possible relationship between them.

\section{Results}

\subsection{Physiochemical Parameters}

Seasonal variation of physicochemical parameter in Muthupet estuary showed highest rainfall in monsoon (226.35mm), followed by post monsoon $130.15 \mathrm{~mm}$, summer 108.60mm and pre monsoon 102.60mm (Table 1). The highest atmospheric temperature was recorded in summer $34.83^{\circ} \mathrm{C}$ and the lowest temperature was recorded in average monsoon $29.95^{\circ} \mathrm{C}$. The water temperature was high in summer $31.10^{\circ} \mathrm{C}$ and low in average monsoon $26.85^{\circ} \mathrm{C}$. The seasonal variations in the water temperature may be associated with the wind force, freshwater discharge influx of the inshore water and atmospheric temperature. The $\mathrm{pH}$ of monsoon, pre monsoon, post monsoon and summer was 7.20, 7.57, 7.43 and 8.07, respectively. The average percentage salinity was low during monsoon months $9.55 \%$, whereas the highest salinity was observed during summer months $32.07 \%$. The maximum dissolved oxygen was found in monsoon months $(7.05 \mathrm{ml} / \mathrm{l})$, followed by post monsoon months $(5.65 \mathrm{ml} / \mathrm{l})$, pre monsoon months $(5.40 \mathrm{ml} / \mathrm{l})$ and found minimum in summer month $(4.77 \mathrm{ml} / \mathrm{l})$.

\subsection{Nutrients}

As mentioned in Table 2, nitrate was highly presented in the monsoon months $(4.43 \mu \mathrm{g} / \mathrm{l})$ and summer months contain least amount of nitrate $1.53 \mu \mathrm{g} / \mathrm{l}$. The amount of phosphate was high during post monsoon (1.49 $\mu \mathrm{g} / \mathrm{l})$, monsoon $(1.36 \mu \mathrm{g} / \mathrm{l})$, pre monsoon $(1.08 \mu \mathrm{g} / \mathrm{l})$ and summer $(0.53 \mu \mathrm{g} / \mathrm{l})$. The seasonal average silicate content in the study area showed maximum values during monsoon and minimum during summer seasons.

\subsection{Primary Productivity}

Average gross primary production was recorded high in summer months $\left(109.72 \mathrm{mg} \mathrm{C} / \mathrm{m}^{3} / \mathrm{hr}\right)$ and lower in monsoon months $\left(27.07 \mathrm{mg} \mathrm{C} / \mathrm{m}^{3} / \mathrm{hr}\right)$. The net primary production during summer, pre monsoon, post monsoon and monsoon months was $\left(97.96 \mathrm{mg} \mathrm{C} / \mathrm{m}^{3} / \mathrm{hr}\right)$, (64.18mg $\mathrm{C} / \mathrm{m}^{3} / \mathrm{hr}$ ), (36.61mg $\mathrm{C} / \mathrm{m}^{3} / \mathrm{hr}$ ) and $\left(27.07 \mathrm{mg} \mathrm{C} / \mathrm{m}^{3} / \mathrm{hr}\right.$ ), respectively. The $\mathrm{F}$ value ranged from 2.405 for net primary production to 3.566 for gross primary production with $\mathrm{P}$ value 0.143 and 0.067 respectively, (Table 3). 
Table 1. Seasonal variations of physicochemical parameters in Muthupet estuary

\begin{tabular}{|c|c|c|c|c|c|c|}
\hline \multirow{2}{*}{ Physicochemical parameters } & \multicolumn{3}{|c|}{ Season } & \multirow{2}{*}{ F. value } & \multirow{2}{*}{ P. value } \\
\cline { 2 - 7 } & Post Monsoon & Summer & Pre Monsoon & Monsoon & & \\
\hline Total Rainfall $(\mathrm{mm})$ & $130.15 \pm 147.27$ & $108.60 \pm 28.04$ & $102.60 \pm 118.26$ & $226.35 \pm 121.13$ & 0.537 & 0.670 \\
\hline Atmospheric Temperature $\left({ }^{\circ} \mathrm{C}\right)$ & $30.85^{\mathrm{a}} \pm 2.49$ & $34.83^{\mathrm{b}} \pm 1.48$ & $31.37^{\mathrm{a}} \pm 0.67$ & $29.95^{\mathrm{a}} \pm 0.07$ & 4.300 & $0.044^{*}$ \\
\hline Water Temperature $\left({ }^{\circ} \mathrm{C}\right)$ & $29.20 \pm 1.70$ & $31.30 \pm 0.52$ & $28.20 \pm 1.01$ & $26.85 \pm 2.62$ & 3.984 & 0.052 \\
\hline $\mathrm{pH}$ & $7.43^{\mathrm{a}} \pm 0.24$ & $8.07^{\mathrm{b}} \pm 0.25$ & $7.57^{\mathrm{a}} \pm 0.31$ & $7.20^{\mathrm{a}} \pm 0.14$ & 5.835 & $0.021^{*}$ \\
\hline Salinity $(\%)$ & $14.77^{\mathrm{a}} \pm 5.51$ & $32.07^{\mathrm{b}} \pm 2.68$ & $19.90^{\mathrm{a}} \pm 8.92$ & $9.55^{\mathrm{a}} \pm 0.64$ & 7.663 & $0.010^{* *}$ \\
\hline Dissolved Oxygen $(\mathrm{ml} / \mathrm{l})$ & $5.65^{\mathrm{a}} \pm 0.59$ & $4.77^{\mathrm{a}} \pm 0.61$ & $5.40^{\mathrm{a}} \pm 0.69$ & $7.05^{\mathrm{b}} \pm 0.07$ & 6.198 & $0.018^{*}$ \\
\hline
\end{tabular}

Different alphabet between seasons in denotes significant at $5 \%$ level using Duncan Multiple Range Test (DMRT), ** denotes significant at $1 \%$ level, * denotes significant at $5 \%$ level

Table 2. Seasonal variations of Dissolved Nutrients ( $\mu \mathrm{g} / 1)$ in Muthupet estuary

\begin{tabular}{|c|c|c|c|c|c|c|}
\hline \multirow{2}{*}{$\begin{array}{l}\text { Dissolved } \\
\text { Nutrients }\end{array}$} & \multicolumn{4}{|c|}{ Season $(\boldsymbol{\mu g} / \mathbf{1})$} & \multirow{2}{*}{ F. value } & \multirow{2}{*}{ P. value } \\
\hline & Post Monsoon & Summer & Pre Monsoon & Monsoon & & \\
\hline Nitrate & $2.54^{\mathrm{b}} \pm 0.57$ & $1.53^{\mathrm{a}} \pm 0.21$ & $1.91^{\mathrm{ab}} \pm 0.47$ & $4.43^{\mathrm{c}} \pm 0.11$ & 19.688 & $0.000^{* *}$ \\
\hline Phosphate & $1.49 \pm 0.47$ & $0.53 \pm 0.29$ & $1.08 \pm 0.51$ & $1.36 \pm 0.23$ & 3.254 & 0.081 \\
\hline Silicate & $59.90^{\mathrm{a}} \pm 19.21$ & $31.17^{\mathrm{a}} \pm 3.52$ & $51.55^{\mathrm{a}} \pm 15.99$ & $89.46^{\mathrm{b}} \pm 13.53$ & 6.141 & $0.018^{*}$ \\
\hline
\end{tabular}

Different alphabet between seasons in denotes significant at 5\% level using Duncan Multiple Range Test (DMRT), ** denotes significant at $1 \%$ level, * denotes significant at $5 \%$ level

Table 3. Seasonal variations of Primary Production (mg C/m³ $/ \mathrm{hr}$ ) in Muthupet estuary

\begin{tabular}{|c|c|c|c|c|c|c|}
\hline \multirow{2}{*}{ Primary Production } & \multicolumn{4}{|c|}{ Season (mg C/m $\mathbf{m}^{\mathbf{3}} / \mathbf{h r}$} & \multirow{2}{*}{ F. value } & \multirow{2}{*}{ P. value } \\
\cline { 2 - 6 } & Post Monsoon & Summer & Pre Monsoon & Monsoon & & \\
\hline Gross Primary Production & $35.67 \pm 2.75$ & $109.84 \pm 34.14$ & $82.78 \pm 61.24$ & $27.85 \pm 1.89$ & 3.566 & 0.067 \\
\hline Net Primary Production & $36.61 \pm 5.33$ & $97.96 \pm 42.70$ & $64.18 \pm 54.06$ & $27.07 \pm 2.04$ & 2.405 & 0.143 \\
\hline
\end{tabular}

Different alphabet between seasons in denotes significant at $5 \%$ level using Duncan Multiple Range Test (DMRT), ** denotes significant at $1 \%$ level, * denotes significant at $5 \%$ level

\subsection{Phytoplankton Community}

Seasonal variation of phytoplankton species of Muthupet estuary was recorded during the period January 2015 to December 2015. The total average density was higher in summer $18541.67 / \mathrm{m}^{3}$, followed by pre monsoon $16405.00 / \mathrm{m}^{3}$, post monsoon $9703.75 / \mathrm{m}^{3}$ and monsoon $6690.00 / \mathrm{m}^{3}$. Phytoplankton species density in summer ranged from $C$. johesianus $\left(2445.00 / \mathrm{m}^{3}\right)$ to $N$. longissima $\left(0.00 / \mathrm{m}^{3}\right)$, whereas in pre monsoon encloses species ranged from B. comosom $\left(2150.33 / \mathrm{m}^{3}\right)$ to $S$. costatum $\left(230.00 / \mathrm{m}^{3}\right)$, respectively. The phytoplankton was higher during post monsoon was associated with high flourishing $C$. oculusiridis $\left(1301.25 / \mathrm{m}^{3}\right)$ and S. costatum $\left(455.00 / \mathrm{m}^{3}\right)$ which sustained low abundance. In similar, C. oculusiridis was found to be maximum and Ceratum sp., was minimum during monsoon. The $\mathrm{F}$ value of the phytoplankton densities ranged from2.177 of $N$. longissima to 17.586 of $A$. japonica with $\mathrm{P}$ value of 0.229 and 0.001 , respectively (Table 4).

Diversity indices of phytoplankton were high during post monsoon for both Simpson and Shannon indices 92 and 2.604, followed by monsoon, pre monsoon and summer. Evenness was also high during post monsoon 0.9658 followed by monsoon, summer and pre monsoon of the plankton species (Table 5). 
Seasonal Variation of Physico-Chemical Parameters and Their Influence on

Phytoplankton Community of Muthupet Estuary, Southeast Coast, Tamil Nadu, India

Table 4. Seasonal variations of Phytoplankton (individuals $/ \mathrm{m}^{3}$ ) in Muthupet estuary

\begin{tabular}{|c|c|c|c|c|c|c|}
\hline \multirow{2}{*}{ Phytoplankton species } & \multicolumn{4}{|c|}{ Season (individuals / $\mathbf{m}^{3}$ ) } & \multirow{2}{*}{ F. value } & \multirow{2}{*}{ P. value } \\
\hline & Post Monsoon & Summer & Pre Monsoon & Monsoon & & \\
\hline \multicolumn{7}{|l|}{ Bacillarophyceae } \\
\hline Asterionella japonica & $667.50^{\mathrm{a}} \pm 175.57$ & $1756.67^{\mathrm{b}} \pm 474.80$ & $1706.67^{\mathrm{b}} \pm 179.26$ & $425.00^{\mathrm{a}} \pm 35.36$ & 17.586 & $0.001^{* *}$ \\
\hline Bacillaria paradoxa & $608.75^{a} \pm 246.72$ & $1746.67^{\mathrm{b}} \pm 410.04$ & $1483.33^{b} \pm 208.17$ & $535.00^{\mathrm{a}} \pm 77.78$ & 14.385 & $0.001^{* *}$ \\
\hline Bacteriastrum comosom & $726.25^{\mathrm{a}} \pm 278.55$ & $2200.00^{\mathrm{b}} \pm 526.78$ & $2150.00^{\mathrm{b}} \pm 694.62$ & $575.00^{\mathrm{a}} \pm 35.36$ & 10.303 & $0.004^{* *}$ \\
\hline Biddulphia aurita & $676.25^{\mathrm{a}} \pm 345.43$ & $1571.67^{\mathrm{b}} \pm 278.22$ & $1516.67^{\mathrm{b}} \pm 28.87$ & $400.00^{\mathrm{a}} \pm 0.00$ & 14.882 & $0.001^{* *}$ \\
\hline Chaetoceros affinis & $685.00^{\mathrm{a}} \pm 213.62$ & $1930.00^{\mathrm{b}} \pm 514.49$ & $1423.33^{\mathrm{b}} \pm 125.03$ & $595.00^{\mathrm{a}} \pm 7.07$ & 13.483 & $0.002^{* *}$ \\
\hline Coscinodiscus johesianus & $1301.25^{\mathrm{ab}} \pm 860.08$ & $2445.00^{\mathrm{b}} \pm 400.09$ & $2003.33^{\mathrm{b}} \pm 462.64$ & $687.50^{\mathrm{a}} \pm 53.03$ & 4.138 & $0.048^{*}$ \\
\hline Coscinodiscus oculusiridis & $1488.75 \pm 965.08$ & $2253.33 \pm 562.17$ & $1846.67 \pm 136.14$ & $737.50 \pm 17.68$ & 2.292 & 0.155 \\
\hline Diploneis bombus & $566.25 \pm 266.06$ & $883.33 \pm 292.97$ & $886.67 \pm 120.55$ & $400.00 \pm 42.43$ & 2.936 & 0.099 \\
\hline Hemidiscus hardmannianus & $520.00 \pm 285.77$ & $676.67 \pm 155.35$ & $830.00 \pm 121.24$ & $340.00 \pm 56.57$ & 2.755 & 0.112 \\
\hline Nitzchia longissima & $480.00 \pm 129.61$ & $0.0 \pm 0.0$ & $525.00 \pm 0.0$ & $687.50 \pm 53.03$ & 2.177 & 0.229 \\
\hline Skeletonema costatum & $455.00 \pm 95.79$ & $0.0 \pm 0.0$ & $230.00 \pm 0.0$ & $390.00 \pm 14.14$ & 3.079 & 0.188 \\
\hline \multicolumn{7}{|l|}{ Dinophyceae } \\
\hline Ceratum sp., & $522.50^{\mathrm{ab}} \pm 273.18$ & $940.00^{\mathrm{b}} \pm 121.66$ & $680.00^{\mathrm{ab}} \pm 242.69$ & $285.00^{\mathrm{a}} \pm 49.50$ & 4.138 & $0.048^{*}$ \\
\hline Noctiluca sp., & $537.50^{\mathrm{ab}} \pm 225.00$ & $896.67^{\mathrm{b}} \pm 279.34$ & $710.00^{\mathrm{b}} \pm 52.92$ & $295.00^{\mathrm{a}} \pm 91.92$ & 4.068 & $0.050 *$ \\
\hline \multicolumn{7}{|l|}{ Cyanophyceae } \\
\hline Trichodesmium erythraem & $582.50 \pm 305.98$ & $1241.67 \pm 484.98$ & $916.67 \pm 189.30$ & $337.50 \pm 17.68$ & 4.023 & 0.051 \\
\hline Total Population Density & $9703.75^{\mathrm{a}} \pm 4122.64$ & $18541.67^{b} \pm 3934.52$ & $16405.00^{b} \pm 1896.60$ & $6690.00^{\mathrm{a}} \pm 452.55$ & 7.459 & 0.011* \\
\hline
\end{tabular}

Different alphabet between seasons in denotes significant at $5 \%$ level using Duncan Multiple Range Test (DMRT), ** denotes significant at $1 \%$ level, * denotes significant at $5 \%$ level

Table 5. Diversity Indices of Phytoplankton in Muthupet estuary

\begin{tabular}{|c|c|c|c|c|c|c|c|c|c|c|c|c|}
\hline Season & \multicolumn{3}{|c|}{ Post Monsoon } & \multicolumn{3}{c|}{ Summer } & \multicolumn{3}{c|}{ Pre Monsoon } & \multicolumn{3}{c|}{ Monsoon } \\
\hline Month & Jan & Feb & Mar & Apr & May & Jun & Jul & Aug & Sep & Oct & Nov & Dec \\
\hline Simpson_1-D & 0.912 & 0.923 & 0.897 & 0.902 & 0.906 & 0.902 & 0.903 & 0.912 & 0.904 & 0.920 & 0.922 & 0.917 \\
\hline Shannon H & 2.54 & 2.604 & 2.42 & 2.398 & 2.416 & 2.396 & 2.408 & 2.518 & 2.411 & 2.583 & 2.595 & 2.559 \\
\hline Evenness_H/S & 0.905 & 0.965 & 0.870 & 0.917 & 0.933 & 0.914 & 0.925 & 0.886 & 0.928 & 0.945 & 0.956 & 0.923 \\
\hline
\end{tabular}

\subsection{Correlation between Phytoplankton and Physicochemical Parameters}

The present study reveals that atmospheric temperature, water temperature, $\mathrm{pH}$ and salinity exhibited the maximum relationship with phytoplankton species. The phytoplankton positively correlated with atmospheric temperature shows highly significant in C. oculusiridis with $\mathrm{r}$ value 0.873 , whereas the water temperature showed significant in Noctiluca sp. with $\mathrm{r}$ value 0.670 . The $\mathrm{pH}$ showed highly significant correlation with $\mathrm{C}$. affinis $\mathrm{r}=$ 0.792 . While salinity showed highly significant correlation in Ceratum sp. $(\mathrm{r}=0.848)$. In dissolved oxygen $N$. longissima only shows positive correlation with $\mathrm{r}$ value 0.475 (Table 6). The N. longissima was only species correlated positively in all the nutrients such as nitrate, phosphate and silicate with $r$ value of $0.451,0.033$ and 0.445 , respectively. The S. costatum was correlated positively in nitrate $(r=0.168)$ and phosphate $(r=0.018)$, while all other species are negatively correlated (Table 7). The gross primary productivity is positively correlated with phytoplankton species $r$ value ranged from non-significant 0.506 of C. oculusiridis to highly significant 0.844 of C. affinis. Similarly, the net primary productivity showed positive correlation with phytoplankton species $r$ value ranged from non-significant 
0.513 of C. oculusiridis to highly significant 0.819 of C. affinis (Table 8).

Table 6. Correlation between Phytoplankton and Physicochemical Parameters of Muthupet estuary

\begin{tabular}{|l|c|c|c|c|c|c|}
\hline Species & Total Rainfall & $\begin{array}{c}\text { Atmospheric } \\
\text { Temperature }\end{array}$ & Water Temperature & $\mathbf{p H}$ & Salinity & Dissolved Oxygen \\
\hline A. japonica & -0.298 & $0.644 *$ & 0.453 & $0.708 * *$ & $0.741 * *$ & $-0.626 *$ \\
\hline B. paradoxa & -0.188 & $0.745 * *$ & 0.444 & $0.728 * *$ & $0.793 * *$ & $-0.609 *$ \\
\hline B. comosom & -0.187 & $0.578 *$ & 0.362 & $0.686 *$ & $0.739 * *$ & $-0.683 *$ \\
\hline B. aurita & -0.392 & $0.750 * *$ & 0.510 & $0.663 *$ & $0.753 * *$ & $-0.649 *$ \\
\hline C. affinis & -0.277 & $0.824 * *$ & 0.570 & $0.792 * *$ & $0.847 * *$ & -0.546 \\
\hline C. johesianus & -0.361 & $0.833 * *$ & $0.582 *$ & $0.639 *$ & $0.817 * *$ & $-0.703 *$ \\
\hline C.oculusiridis & -0.317 & $0.873 * *$ & 0.564 & 0.518 & $0.694 *$ & $-0.606 *$ \\
\hline D. bombus & -0.335 & $0.750 * *$ & 0.464 & 0.474 & $0.671 *$ & -0.552 \\
\hline H. hardmannianus & -0.344 & $0.587 *$ & 0.320 & 0.428 & 0.550 & $-0.588 *$ \\
\hline N. longissima & -0.197 & -0.093 & -0.106 & -0.543 & -0.357 & 0.475 \\
\hline S. costatum & 0.339 & -0.758 & 0.029 & 0.217 & -0.029 & -0.265 \\
\hline Ceratum sp., & -0.288 & $0.836 * *$ & $0.611 *$ & $0.664 *$ & $0.848 * *$ & $-0.796 * *$ \\
\hline Noctiluca sp., & -0.439 & $0.800 * *$ & $0.670 *$ & $0.647 *$ & $0.750 * *$ & $-0.613 *$ \\
\hline T. erythraem & -0.376 & $0.769 * *$ & $0.648 *$ & $0.718 * *$ & $0.771 * *$ & $-0.604 *$ \\
\hline
\end{tabular}

Correlation is significant at the 0.01 level (2-tailed). ${ }^{* *}$ denotes significant at $1 \%$ level, $*$ denotes significant at $5 \%$ level

Table 7. Correlation between Phytoplankton and Nutrient of Muthupet estuary

\begin{tabular}{|l|c|c|c|}
\hline Species & Nitrate & Phosphate & Silicate \\
\hline A. japonica & $-0.758 * *$ & $-0.636 *$ & $-0.721 * *$ \\
\hline B. paradoxa & $-0.698 *$ & $-0.705 *$ & $-0.734 * *$ \\
\hline B. comosom & $-0.702 *$ & $-0.714 * *$ & $-0.719 * *$ \\
\hline B. aurita & $-0.798 * *$ & $-0.607 *$ & $-0.765 * *$ \\
\hline C. affinis & $-0.703 *$ & $-0.697 *$ & $-0.748 * *$ \\
\hline C. johesianus & $-0.768 * *$ & $-0.635 *$ & $-0.848 * *$ \\
\hline C.oculusiridis & $-0.692 *$ & -0.475 & $-0.784 * *$ \\
\hline D. bombus & $-0.676 *$ & -0.439 & $-0.727 * *$ \\
\hline H. hardmannianus & $-0.679 *$ & -0.482 & $-0.669 *$ \\
\hline N. longissima & 0.451 & 0.033 & 0.445 \\
\hline S. costatum & 0.168 & 0.018 & -0.049 \\
\hline Ceratum sp., & $-0.759 * *$ & $-0.674 *$ & $-0.888 * *$ \\
\hline Noctiluca sp., & $-0.769 * *$ & -0.495 & $-0.766 * *$ \\
\hline T. erythraem & $-0.724 * *$ & $-0.594 *$ & $-0.757 * *$ \\
\hline
\end{tabular}

Correlation is significant at the 0.01 level (2-tailed). ** denotes significant at $1 \%$ level, * denotes significant at $5 \%$ level

Table 8. Correlation between Phytoplankton and Productivity of Muthupet estuary

\begin{tabular}{|l|c|c|}
\hline \multicolumn{1}{|c|}{ Species } & $\begin{array}{c}\text { Gross Primary } \\
\text { Production }\end{array}$ & $\begin{array}{c}\text { Net Primary } \\
\text { Production }\end{array}$ \\
\hline A. japonica & $0.797 * *$ & $0.755^{* *}$ \\
\hline B. paradoxa & $0.789 * *$ & $0.759 * *$ \\
\hline B. comosom & $0.766 * *$ & $0.732 * *$ \\
\hline B. aurita & $0.736 * *$ & $0.682 *$ \\
\hline C. affinis & $0.844^{* *}$ & $0.819 * *$ \\
\hline C. johesianus & $0.701 *$ & $0.692 *$ \\
\hline C.oculusiridis & 0.506 & 0.513 \\
\hline D. bombus & $0.578 *$ & 0.564 \\
\hline H. hardmannianus & 0.550 & 0.539 \\
\hline N. longissima & -0.279 & -0.390 \\
\hline S. costatum & -0.703 & -0.416 \\
\hline Ceratum sp., & $0.630 *$ & $0.642 *$ \\
\hline Noctiluca sp., & $0.685 *$ & $0.711 * *$ \\
\hline T. erythraem & $0.776 * *$ & $0.815 * *$ \\
\hline
\end{tabular}

Correlation is significant at the 0.01 level (2-tailed). ** denotes significant at $1 \%$ level, * denotes significant at $5 \%$ level 


\section{Discussion}

The physicochemical parameters such as temperature, $\mathrm{pH}$, salinity, dissolved oxygen and nutrients showed seasonal variations. The seasonal variations of the environmental features in the lagoon are primarily control by the spectacular regime of the rainfall during monsoon. In the present study area, the peak values of rainfall were recorded during the northeast monsoon periods (October-December). The rainfall was scanty during post monsoon and summer months. Commendable works are available on Vellar estuary [23], Point Calimere costal water [24], Parangipettai coast [25, 26] and Muttukadu backwaters [27].

Temperature is universal factor in the aquatic ecosystem, which influences the physicochemical characteristics and also influences the life of organisms [28]. The reduction in the water temperature mainly depends upon the intensity of rainfall during monsoon and the low air temperature existed at the time. Similar observations have been reported by previous findings [10, 29, 30]. Generally, low $\mathrm{pH}$ values were record values during monsoon period and slightly higher values during summer period. Similar seasonal pattern was recorded earlier by Santhanam and Perumal [25], Palpandi [29] and Fatema et al. [31]. Minimum values of $\mathrm{pH}$ during monsoon in the study area may be controlled by the influence of freshwater discharge, rainfall and also due the decomposition of organic matter as stated by Ragothaman and Patil [32] and Upadhaya [33].

The salinity acts as a prime factor that can be attributed to controls the distributions of all living organisms in coastal ecosystems [34, 35]. The intrusion of neritic water and low river discharge may be responsible for high salinity, the monsoonal rain and continuous flow of the freshwater of the rivers may be responsible for low salinity in the present study in conformity with the earlier report of Sukumaran et al. [28]. Dissolved oxygen, is a major component in environmental parameter that determines the ecological health of a watercourse and act as a shield in aquatic life [36]. Dissolved oxygen contents showed well-marked seasonal variations in the Muthupet estuary. This can be control by various factors such as rainfall, temperature, phytoplankton photosynthesis and salinity. The dissolved oxygen content was high during monsoon period in the study area this could be due to the influx of fresh water during the monsoon, higher solubility and low salinity. Similar observations have been reported from the Vellar estuary [23, 37], Point Calimere coastal water [24] and Egyptian north western red sea [34].

The seasonal variation of nutrients like nitrate, phosphate and silicate was based on rainfall, freshwater input, tidal ingress and utilization of nutrients by phytoplanktons in aquatic environment. The nitrate content was high in monsoon is mainly due to the river water discharge from agricultural fields containing nitrogenous particles of various origins. Low values of nitrate observed during summer seasons might be due to the lesser amount of freshwater in flow and higher salinity. Similar pattern results were also recorded in Parangipettai coastal waters $[10,26]$ and Thondi coastal waters [38].

Phosphate is a major nutrient for primary productivity in aquatic ecosystem, which enhance growth of organisms and confines the phytoplankton production [39, 40]. In the present study, the high concentration of phosphate during monsoon seasons may be due to heavy rainfall, decomposition of particulate organic matter, industrial effluents and from the agricultural discharges from the adjacent lands. Lower concentration of Phosphate in summer was accounted by earlier reports [41, 42]. The peak values of silicate observed during monsoon may attributed to the heavy fresh water influx and land run off which carry slit and other silicon deposits from upper reaches of the river. Observations similar to present study were reported earlier by Qasim et al. [43]; Ansari and Rajagopal [18] in Cochin back waters, Nair et al. [44] in Ashtamudi estuary and Praba Devi [45] in Coleroon estuary.

The physicochemical parameters, salinity and nutrients have been recognized as the major factors controlling primary production [46]. The low values of primary productivity recorded during monsoon could be due to the cloudy weather, low values of salinity and low water temperature. The advent monsoon tilts the whole picture of the flora; it inactivates the marine species by fresh water species in this season. The high productivity in summer season could be attributed to the high light intensity, high salinity and high density of phytoplankton, clear water condition and availability of nutrients. This is an agreement with the earlier observations of Dehadrai and Bharagava [47] in Mandovi and Zuari estuaries, Tillai Rajsekar et al. [48] in Coleroon estuary and Rajesh et al. [46] in Nethravathi estuary, Mangalore. According to Nair and Tampi [49], the peak primary productivity during summer period coincides with the amount of solar energy reaching the surface of the water. In the present investigation, the net primary production is followed the pattern of gross primary production throughout the study period. Similar observations were made by Selvaraj et al. [50] and Ranjith et al. [51] from Cochin backwaters, Meera and Bijoy Nandan [52] from Valanthakad backwater in Kerala.

The present study reveals that atmospheric temperature, water temperature, $\mathrm{pH}$ and salinity exhibited the maximum relationship with phytoplankton species, this is an agreement with previous report [10] the correlation between phytoplankton and physicochemical parameters like total rainfall showed negative correlation with most of the phytoplankton species except $S$. costatum with $\mathrm{r}$ value 0.339 respectively. The density of species in the Bacillariophyceae family has positive correlation, the similar statement was recorded by Trombetta et al. [53]. Temperature is important environmental factor can induce the phytoplankton metabolic rates [54]. The positive 
correlations between $\mathrm{pH}$ and the diversity indices indicate the productivity of the Minnie Bay water in pre-monsoon and post-monsoon seasons associated with decomposition of organic matter [55]. In the present study, salinity has marked influence on the phytoplankton production. Similarly, Gopinath et al. [56] from Parangipettai and Nagapattinam Coastal waters reported that the salinity and primary productivity in general showed positive correlation.

The maximum of species from Bacillariophyceae have negative correlation with nutrients. The similar correlation results were found in earlier reports in Tungabhadra River [57] and Garhwal Himalayas [16]. The increasing of water temperature enhances primary production and results in biomass accumulation and phytoplankton community [53]. The ratio of net and gross primary production is essential for the evaluation of total gross production obtainable to the consumer [58]. The importance of primary production was reported by earlier studies [59, 60, 61, 62].

\section{Conclusions}

The present study examines the seasonal variation in physiochemical parameters on phytoplankton community at Muthupet estuary. The correlation results proved that the physiochemical parameters are important for distribution, abundance and occurrence of phytoplankton species with esteemed to seasonal changes in environmental parameters. Based on the present observation, Muthupet estuary is rich in species diversity and composition and the nutrient status is high enough to support the plankton community.

\section{Acknowledgements}

The authors would like to thank Director, Zoological Survey of India, Kolkata for providing facilities. We also thank to authorities of Marine Biology Regional Centre (MBRC), Zoological Survey of India for their constant support.

\section{REFERENCES}

[1] Mitsch W J and Gosselink J G. Wetlands, vol. 1. John Wiley Sons, Inc., Estados Unidos, 2007.

[2] Suganthi A, Venkatraman C, Bharath B and Perinbam K. Influence of Physio-Chemical Parameters on Fish Diversity in Muthupet Estuary, Southeast Coast of India. International Journal of Scientific Research in Biological Sciences, 54, 66-75, 2018.

[3] Thomaz S M, Bini L M and Bozelli R L. Floods increase similarity among aquatic habitats in river-floodplain systems. Hydrobiologia, 579, 1-13, 2007.
[4] Ward J V and Tockner K. Biodiversity: towards a unifying theme for river ecology. Freshwater Biology, 46, 807-819, 2001.

[5] Cardoso S J, Roland F, Loverde-Oliveira S M and de M. Huszar V L. Phytoplankton abundance, biomass and diversity within and between Pantanal wetland habitats. Limnologica - Ecology and Management of Inland Waters, 423, 235-241, 2012.

[6] Vasanthi P and Sukumaran M. Physicochemical analysis of coastal water of east coast of Tamil Nadu Muthupet estuary. International Journal of Zoology Studies, 25, 15-21, 2017.

[7] Rajkumar J S I, John Milton M C and Ambrose T. Seasonal variation of water quality parameters in Ennore estuary with respect to industrial and domestic sewage, International Journal of Current Research, 333, 209 -218, 2011.

[8] Khan T A. Limnology of four saline lakes in western Victoria, Australia. Limnologica 334, 327-339, 2003.

[9] Falkowski P G, Fenchel T and Delong E F. The microbial engines that drive Earth's biogeochemical cycles. Science, 3205879, 1034-1039, 2008.

[10] Vajravelu M, Martin Y, Ayyappan S and Mayakrishnan M. Seasonal influence of physico-chemical parameters on phytoplankton diversity, community structure and abundance at Parangipettai coastal waters, Bay of Bengal, South East Coast of India. Oceanologia, 602, 114-127, 2018.

[11] Hulyal S B and Kaliwal B B. Dynamics of phytoplankton in relation to physico-chemical factors of Almatti reservoir of Bijapur district, Karnataka State. Environ. Monit. Assess. 153, 45-59, 2009.

[12] Sharma R C, Singh N and Chauhan A. The influence of physico-chemical parameters on phytoplankton distribution in a head water stream of Garhwal Himalayas: A case study. The Egyptian Journal of Aquatic Research, 421, 11-21, 2016.

[13] Srinivasan V, Usha N and Anitha P. Seasonal Variability of Coastal Water Quality in Bay of Bengal and Palk Strait, Tamil Nadu, Southeast Coast of India. Brazilian Archives of Biology and Technology, 565: 875-884, 2013.

[14] Ravichelvan R, Ramu S and Anandaraj T. Seasonal variations of water quality parameters in south east coastal waters of Tamil Nadu, India. International Journal of Modern Research and Reviews, 310, 826-829, 2015.

[15] Altaff K. A Manual of Zooplankton. University Grants Commission, New Delhi, p 1-145, 2004.

[16] Jayaraman R. Seasonal variations in salinity, dissolved oxygen and nutrient salts in the inshore waters of the Gulf of Mannar and Palk near Mandapam. Indian Journal of Marine Sciences, 1, 345-364, 1954.

[17] Nunes M L, Batisa I and Morcio de Campos V. Physical, chemical and sensory analysis of sardine Sardine pilchardis stored in ice. Journal of the Science of Food and Agriculture, 59, 37-43, 1992.

[18] Ansari S A and Rajagopal M D. Distribution of mud phosphate in the Cochin backwater. Mahasagar -- Bulletin of the National Institute of Oceanography, 7, 69-72, 1974. 
[19] Gouda R and Panigrahy R C. Ecology of phytoplankton in coastal waters of Gopalpur, East coast of India. Indian Journal of Marine Sciences, 25, 81-84, 1996.

[20] Strickland J D H and Parsons T R. A practical hand book of seawater analysis. Fisheries Research Board of Canada Bull, 167, 311 p, 1972.

[21] Desikachary T V. Cyanophyta, ICAR, New Delhi, 1959.

[22] Santhanam R, Ramanathan N, Venkataramanujam KV and Jegathesan G. Phytoplankton of the Indian seas. Aspects of Marine Botany, Daya Publishing House, Delhi. 127, 2007.

[23] Nedumaran T, Ashok Prabu V and Perumal P. Ecology of phytoplankton of Vellar estuary, southeast coast of India. Seaweed Research and Utilisation, 23 12, 157- 162, 2001.

[24] Damotharan P, Vengadesh Perumal N, Arumugam M, Vijayalakshmi S and Balasubramanian T. Seasonal variation of physico-chemical characteristics in point Calimere coastal waters South East Coast of India. Middle-East Journal of Scientific Research, 64, 333-339, 2010.

[25] Santhanam P and Perumal P. Diversity of zooplankton in Parangipettai coastal waters, South east coast of India. Journal of the Marine Biological Association of India, 452, 144-151, 2003.

[26] Sundaramanickam A, Sivakumar T, Kumaran R, Ammaiappan V and Velappan R. A comparative study of physico-chemical investigation along Parangipettai and Cuddalore coast. Journal of Environmental Science and Technology, 1, 1-10, 2008.

[27] Prema M and Subramanian B. Hydrobiological parameters of Muttukadu backwater of Bay of Bengal. Indian Hydrobiology, 612, 95-100, 2003.

[28] Sukumaran M, Muthukumaravel K and Sivakami R. Seasonal variation in physico-chemical characteristics of Agniar Estuary, Southeast Coast of India. Asia-Pacific Journal of Research, 28, 108-120, 2013.

[29] Soundarapandian P, Preamkumar T and Dinakaran G K. Studies on the phyisco- chemical characteristics and nutrients in the Uppanar estuary of Cuddalore, South east coast of India. Current Research Journal of Biological Sciences, 13, 102-105, 2009.

[30] Palpandi P. Hydrobiological parameters, pollution density and distribution pattern in the gasdropod Nerita dostia crepidularia Lamarck, 1822, from mangroves of Vellar estuary, southeast India. International Journal of Biodiversity and Conservation. 34, 121-130, 2011.

[31] Fatema K, Wan Maznah W O and Isa M M. Spatial variation of water quality parameters in a mangrove estuary. International Journal of Environmental Science and Technology, 126, 2091-2102, 2015.

[32] Ragothaman G and Patil T. Studies on the physico-chemical parameters and phytoplankton of Narmada estuary. Enviromedia, 142, 221-226, 1995.

[33] Upadhaya S. Physico-chemical characteristics of the Mahanadi estuarine ecosystem, east coast of India. Indian Journal of Marine Sciences, 17, 19-23, 1998.

[34] Nassar M Z, Mohamed H R, Khiray H M and Rashedy S H.
Seasonal fluctuations of phytoplankton community and physico-chemical parameters of the north western part of the Red Sea, Egypt. The Egyptian Journal of Aquatic Research, 404, 395-403, 2014.

[35] Sridhar R, Thangaradjou T, Senthil Kumar S and Kannan L. Water quality and phytoplankton characteristics in the Palk Bay, Southeast coast of India. Journal of Environmental Biology, 273, 561-566, 2006.

[36] Chang H. Spatial and temporal variations of water quality in the river and its tributaries, Seoul, Korea, 1993-2002. Water, Air, Soil Pollution, 161, 267-284, 2002.

[37] Brinda S, Srinivasan M and Balakrishnan S. Studies on diversity off in fish larvae in Vellar estuary, southeast coast of India. World Journal of Fish and Marine Sciences, 21, 44-50, 2010.

[38] Hari M, Abhilash and Ramasubbu R. Physico-chemical parameters and planktors analysis of seawater of Thondi of Palk Bay, Tamil Nadu. Journal of Bioscience and Agriculture Research, 11: 20-24, 2010.

[39] Redfield A C. On the proportion of organic derivations in sea water and their relation to the composition of plankton. Jame Johnston Memorial Volume, University Press of Liverpool, 176-192, 1934.

[40] Cole C V and Sanford R L. Biological aspects of the Phosphorus cycle. In: Proceedings of a Symposium "Phosphorous require-ments for sustainable agriculture in Asia and Oceania March 6-10 1989”. SCOPE/UNEP, 1989, International Rice Research Institute, 497 pp, 1989.

[41] Satpathy K K, Mohanty A K, Natesan U, Prasad M V R and Sarkar S K. Seasonal variation in physico - chemical properties of coastal water of Kalpakkam East Coast of India with special emphasis on nutrients. Environmental Monitoring and Assessment, 164,153 - 171, 2009.

[42] Perumal N V, Rajkumar M, Perumal P, Rajasekar K T. Seasonal variations of plankton diversity in the Kaduviyar estuary, Nagapattinam, southeast coast of India. Journal of Environmental Biology, 306, 1035-1046, 2009.

[43] Qasim S Z, Wellershaus S, Bhattathiri P M A and Abidi S A $\mathrm{H}$. Organic production in a tropical estuary. Proceedings of the Indian Academy of Sciences - Section B, 69, 51-94, 1969.

[44] Nair N B, Abdul Azis P K, Dharmaraj K, Arunachalam M, Krishnakumar K and Balasubramanian N K. Ecology of Indian estuaries: Part V: Primary productivity of Ashtamudi estuary, South West Coast of India. Proceedings of the Indian Academy of Sciences Animal Sciences, 931: 9-23, 1983.

[45] Prabha Devi L. Hydrobiological studies in tidal zone of the Coleroon estuary. Ph.D. Thesis. Annamalai Univesity, 241pp, 1986.

[46] Rajesh K M, Gowda G and Mendon M R. Primary Productivity of the brackish water impoundments along Nethravathi estuary, Mangalore in relation to some physico-chemical parameters. Fishery Technology, 39, 8587, 2002.

[47] Dehadrai P V and Bhargava R M S. Seasonal organic production in relation to the environmental features in Mandovi and Zuari estuaries, Goa. Indian Journal of Marine 
Sciences, 1: 52-56, 1972.

[48] Thillai Rajasekar K, Perumal P and Santhanam P. Phytoplankton diversity in the Coleroon estuary, Southeast coast of India. Journal of the Marine Biological Association of India, 47, 127-132, 2005.

[49] Nair N B and Tampi D M. A text book of marine ecology (India: The MacMillan Company of India Ltd.,) p 352. 1980.

[50] Selvaraj C S D, Thomas V J and Khambadkar I R. Seasonal variation of phytoplankton and productivity in the surf zone and backwater at Cochin. Journal of the Marine Biological Association of India, 451, 9-19, 2003.

[51] Ranjith K R, Varma K K, Haridevi C K, Houlath K H, Vijayakumar C T and Praba Joseph. Primary production and fistery potential of the Panangad region in the Cochin estuarine System. Journal of the Marine Biological Association of India, 46, 126-132, 2004.

[52] Meera S and Bijoy Nandam S. Water quality status and primary productivity of Valanthakad backwater in Kerala. Indian Journal of Marine Sciences, 391, 105-113, 2010.

[53] Trombetta T, Vidussi F, Mas S, Parin D, Simier M and Mostajir B. Water temperature drives phytoplankton blooms in coastal waters. PLoS ONE, 144: e0214933, 2019.

[54] Rajkumar M, Perumal P, Ashok P V, Vengadesh Perumal N and Thillai Rajasekar K. Phytoplankton diversity in Pichavaram mangrove waters from south east coast of India. Journal of Environmental Biology, 304, 489-498, 2009.

[55] Dayala Salas V P and Sujatha C. Spatial and seasonal variations of phytoplankton species and their relationship to physicochemical variables in the Cochin estuarine waters, Southwest coast of India. Indian Journal of Marine Sciences, 43, 937-947, 2014.

[56] Gopinath M, Jayasudha S, Umamageswari P and Sampathkumar P. Physico-biochemical variations in Parangipettai and Nagapattinam Coastal waters, Southeast coast of India. International Journal of Research in Biological Sciences, 34: 149-156, 2013.

[57] Suresh B, Manjappa S and Puttaiah E T. Dynamics of phytoplankton succession in Tungabhadra River near Harihar, Karnataka India. Journal of Microbiology and Antimicrobials, 57, 65-71, 2013.

[58] Singh A K and Singh D K. A comparative study of the phytoplanktonic primary production of river Ganga and pond of Patna Bihar, India. Journal of Environmental Biology, 20, 263-270, 1999.

[59] Hashimoto S, Horimoto N, Yamaguchi Y, Ishimaru T and Saino T. Relationship between net and gross primary production in the Sagami Bay, Japan. Limnology and Oceanography, 506, 1830-1835, 2005.

[60] Sultana M and Khondker M. Assessment of phytoplankton primary productivity of two urban pond ecosystems of Bangladesh. Dhaka University Journal of Biological Sciences, 182, 127-135, 2009.

[61] Tiselius P, Belgrano A, Andersson L and Lindahl O. Primary productivity in a coastal ecosystem: a tropic perspective on a long-term time series, Journal of Plankton Research, 384, 1092-1102, 2016.
[62] Kang J, Liang Q, Wang J, Lin Y, He X, Xia Z, Zheng X and Wang Y. Size structure of biomass and primary production of phytoplankton: environmental impact analysis in the Dongsha natural gas hydrate zone, northern South China Sea. Acta Oceanologica Sinica, 371, 97-107, 2017. 